\title{
PENGARUH PENDIDIKAN KEWIRAUSAHAAN DAN KEPRIBADIAN TERHADAP MINAT BERWIRAUSAHA SISWA KELAS XI SMK NEGERI 4 BALIKPAPAN TAHUN AJARAN 2017/2018
}

\author{
Haida Apriana ${ }^{1}$, Tutik Yuliani ${ }^{2}$, Tri Astuti Nur'aini ${ }^{3}$ \\ Universitas Balikpapan $^{1}$, Universitas Balikpapan ${ }^{2}$, Universitas Balikpapan ${ }^{3}$ \\ Pos-el : haida.apriana@gmail.com¹, tutik.yuliani@uniba-bpn.ac.id ${ }^{2}$, \\ tri.astuti@uniba-bpn.ac.id ${ }^{3}$
}

\begin{abstract}
ABSTRAK
Penelitian ini bertujuan untuk mengetahui apakah terdapat pengaruh secara parsial dan simultan antara pendidikan kewirausahaan dan kepribadian terhadap minat berwirausaha siswa kelas XI SMK Negeri 4 Balikpapan. Sampel dalam penelitian ini adalah seluruh siswa kelas XI SMK Negeri 4 Balikpapan sebanyak 79 siswa. Pengumpulan data dilakukan dengan cara mengisi kuesioner wawancara dan dokumentasi. Teknik analisis data menggunakan analisis deskriptif dan analisis regresi berganda. Hasil dari analisis regresi berganda penelitian ini yaitu $\mathrm{Y}=1,587+$ $0,070 \mathrm{X} 1+0,419 \mathrm{X} 2$. Hasil penelitian ini adalah kepribadian $\left({ }_{2}\right)$ berpengaruh terhadap minat berwirausaha (Y). Sedangkan pendidikan kewirausahaan( $\left.{ }_{1}\right)$ tidak berpengaruh terhadap minat berwirausaha $(\mathrm{Y})$. Pendidikan kewirausahaan dan kepribadian secara bersama-sama memiliki pengaruh terhadap minat berwirausaha siswa kelas XI SMK Negeri 4 Balikpapan.
\end{abstract}

Kata Kunci : Pendidikan Kewirausahaan, Kepribadian, Minat Berwirausaha

\begin{abstract}
This study aims to determine whether there is a partial and simultaneous influence between entrepreneurship education and personality on entrepreneurial interest in class XI students of SMK Negeri 4 Balikpapan. The sample in this study were all students of class XI of SMK Negeri 4 Balikpapan as many as 79 students. Data collection was done by filling out interview questionnaires and documentation. Data analysis techniques using descriptive analysis and multiple regression analysis. The results of the multiple regression analysis of this study are $Y=1,587+0,070 \mathrm{X1}$ $+0,419 X 2$. The results of this study are personality (X2) influencing the interest in entrepreneurship $(Y)$. While entrepreneurship education

(XI) does not affect the interest in entrepreneurship (Y). Entrepreneurship and personality education together have an influence on entrepreneurial interest in class XI students of SMK Negeri 4 Balikpapan.
\end{abstract}

Keywords: Entrepreneurship Education, Personality, Entrepreneurial Interest

Jurnal Edueco Volume 2 Nomor 1 Juni 2019 


\section{PENDAHULUAN}

Lulusan SMK disiapkan untuk bekerja sesuai dengan kompetensi keahlian mereka. Namun, jika lapangan pekerjaan tidak tersedia maka lulusan SMK akhirnya akan

sulit mendapatkan pekerjaan kemudian menjadi tidak bekerja. Untuk itu sangatlah penting membuat alternatif pekerjaan yang sesuai dan cocok dengan keterampilan, bakat dan minat. Salah situ pilihannya yaitu dengan membuka usaha mandiri.

Maka dari itu saat ini pendidikan kewirausahaan telah diajarkan di sekolah-sekolah untuk membangun minat siswa dalam

berwirausaha. Khsusnya SMK (Sekolah Menengah Kejuruan) yang memang menyiapkan siswanya untuk siap terjun langsung ke dalam dunia usaha atau industri. Sekolah Menengah Kejuruan (SMK) merupakan salah satu pendidikan menengah yang menyiapkan lulusannya untuk menjadi tenaga kerja yang terampil, produktif, kreatif, serta dapat mengembangkan sikap professional di bidangnya.

\section{Menurut Subjianto (Rifai dan}

Sucihatiningsih, 2016) "dalam mempersiapkan lulusan SMK, pemberian materi di SMK lebih menekankan pada penguasaan tertentu agar lebih siap bekerja di bidang tertentu". Lulusan SMK disiapkan untuk bekerja dengan kompetensi yang spesifik. Dengan kata lain, bagi lulusan SMK lebih dipersiapkan untuk menguasai keterampilan tertentu. Hal ini dapat dimaknai bahwa lulusan SMK lebih dipersiapkan untuk bekerja atau hidup mandiri di lingkungan masyarakat.

Adapun dalam penelitian ini sekolah SMK yang dipilih oleh peneliti sebagai lokasi penelitian adalah SMK Negeri 4 Balikpapan

dengan alasan jurusan atau kompetensi keahlian yang ada di SMK Negeri 4 Balikpapan sesuai dengan tema penelitian yang diambil oleh peneliti. Kompetensi keahlian yang ada di SMK Negeri 4 Balikpapan antara lain akomodasi perhotelan, tata boga, teknik kecantikan rambut, tata busana dan patiseri.

SMK Negeri 4 Balikpapan mempersiapkan para siswanya untuk terjun langsung dalam berwirausaha. Pihak sekolah maupun guru mata pelajaran memberikan peluang untuk siswa dalam melakukan wirausaha dan beberapa dari mereka memiliki minat atau ketertarikan untuk berwirausaha dapat dilihat dalam praktik kewirausahaannya para siswa diajarkan untuk mengolah sendiri sesuatu yang hendak mereka pasarkan dalam praktik kewirausahaan baik itu berupa makanan barang atau jasa yang akan mereka pasarkan di dalam sekolah maupun lingkungan sekitar sekolah.

Minat berwirausaha tidak dibawa sejak lahir tapi tumbuh dan berkembang sesuai dengan faktorfaktor yang mempengaruhi. Faktor yang mempengaruhi tumbuhnya

keputusan untuk berwirausaha merupakan hasil interaksi dari beberapa faktor yaitu karakter

kepribadian seseorang dan 
lingkungannya. Minat wirausaha dipengaruhi oleh beberapa faktor, menurut Hendro (Rifai, dan Sucihatiningsih, 2016) terdapat faktor-faktor yang mempengaruhi minat berwirausaha, antara lain (1)

Faktor infividual/personal,

Pendidikan, (3) Dorongan,

Keterpaksaan dan Keadaan,

Fasilitas.

Dari beberapa faktor yang mempengaruhi minat berwirausaha salah satunya adalah pendidikan. Bentuk upaya yang di lakukan sekolah untuk menumbuhkan minat berwirausaha siswa adalah dengan cara menerjunkan langsung siswa ke dunia usaha atau industri melalui program pelatihan yang diterima oleh masing-masing siswa sesuai dengan kompetensi keahlian mereka sehingga siswa mampu merasakan pengalaman praktik dan bagaimana cara bersaing di lingkungan masyarakat. Pelaksanaaan pembelajaran kewirausahaan di SMK akan memberikan pengaruh pada minat berwirausaha siswa. Pendidikan kewirausahaan dapat membentuk pola pikir, sikap, dan perilaku pada siswa menjadi seorang wirausahawan sejati sehingga mengarahkan mereka untuk memilih berwirausaha sebagai pilihan karir. Hal ini didukung oleh penelitian yang dilakukan oleh Ni Luh Wahyuni W.P, (2014) "Pengaruh Pendidikan Kewirausahaan Terhadap Minat Mahasiswa Untuk Berwirausaha" pada penelitian tersebut didapatkan hasil adanya hubungan positif yang signifikan antara pendidikan kewirausahaan dengan minat berwirausaha.
Faktor lain yang berpengaruh terhadap minat siswa dalam berwirausaha menurut Alma (2013:52) adalah kepribadian. Kepribadian merupakan sifat dasar yang dimiliki seseorang yang membedakannya dengan orang lain. Wirausahawan yang berhasil pada dasarnya harus memiliki kepribadian yang unggul, sehingga memiliki kreativitas tinggi serta keberanian yang besar dalam mengambil risiko. Alma (Citradewi dan Margunani, 2016) mengatakan "bahwa dengan kepribadian yang dimiliki seseorang dapat memikat orang lain untuk simpati padanya, tertarik dengan pembicaraan dan terkesima olehnya.

Wirausahawan yang memiliki kepribadian seperti itulah yang seringkali berhasil dalam menjalankan usahanya.

Faktor pendidikan dan kepribadian akan berpengaruh terhadap keinginan siswa dalam berwirausaha dan lama kelamaan akan menimbulkan minat siswa dalam berwirausaha. Djaali (Iswandari, 2013) mengemukakan "minat adalah rasa lebih suka dan rasa ketertarikan pada suatu hal atau aktivitas, tanpa ada yang menyuruh". Minat siswa untuk berwirausaha tidak timbul begitu saja tanpa ada faktor-faktor

yang mendukung. Menurut McClelland (Iswandari, 2013)"yang mempengaruhi minat seseorang dalam berwirausaha yaitu motivasi, pengalaman, dan kepribadian". Rendahnya minat siswa untuk berwirausaha juga dikarenakan kurang adanya dorongan dalam diri siswa atau motivasi yang menumbuhkan minat berwirausaha. 
Mereka berpikir bahwa untuk berwirausaha mereka akan dihadapkan pada situasi yang tidak pasti, dibutuhkan modal yang besar, penuh dengan tantangan dan risiko sehingga mereka takut gagal. Fua'di (Putri, 2014) mengatakan "minat

berwirausaha adalah keinginan, ketertarikan serta ketersediaan untuk bekerja keras atau berkemauan keras atau berusaha untuk memenuhi kebutuhan hidupnya tanpa merasa takut dengan resiko yang akan terjadi, serta berkemauan keras untuk belajar dari kegagalan".

Adapun berdasarkan hasil observasi dan wawancara dengan guru mata pelajaran kewirausahaan di SMK Negeri 4 Balikpapan ditemukan alasan mengapa masih kurangnya minat siswa dalam berwirausaha, yaitu karena kurangnya modal untuk mulai berwirausaha kebanyakan dari mereka tidak memulai wirausahanya sendiri melainkan hanya menjual produk yang dibuat di sekolah pada saat praktik kewirausahaan produk tersebut kebanyakan berupa makanan ringan atau kue yang mudah untuk dipasarkan di sekolah maupun di lingkungan sekitar sekolah. Pada saat mata pelajaran kewirausahaan maupun praktiknya siswa tidak hanya diajarkan untuk sekedar menjual hasil usahanya kepada konsumen tetapi siswa juga diajarkan bagaimana berkepribadian yang harus dimiliki seorang wirausaha dalam mengembangkan usahanya kelak.

Selain melakukan wawancara dengan guru mata pelajaran kewirausahaan peneliti juga melakukan wawancara dengan beberapa siswa yang melakukan praktik kewirausahaan di sekolah. Ditemukan alasan yang menyebabkan rendahnya minat mereka dalam berwirausaha yaitu, mereka takut untuk memulai berwirausaha karena tidak siap untuk mengahadapi risiko kegagalan sebagian dari mereka mengatakan lebih tertarik untuk bekerja pada bidang industri atau

perusahaan dibandingkan untuk berwirausaha dan sebagian siswa lain lebih memilih untuk melanjutkan pendidikan ke perguruan tinggi.

Sesuai dengan rumusan masalah di atas, maka tujuan penelitian ini adalah untuk mengetahui apakah ada pengaruh pendidikan kewirausahaan dan kepribadian terhadap minat berwirausaha siswa kelas XI SMK Negeri 4 Balikpapan.

\section{METODE PENELITIAN}

Penelitian ini dilakukan di Jurusan Pendidikan Ekonomi, FKIP Universitas Balikpapan angkatan tahun 2014 dengan fokus pengamatan pada pendidikan kewirausahaan khususnya mata pelajaran kewirausahaan terhadap minat siswa untuk berwirausaha. Jenis penelitian ini adalah ex post facto, yaitu penelitian yang dilakukan untuk meneliti peristiwa yang telah terjadi kemudian meruntut ke belakang untuk mengetahui faktor-faktor yang dapat menimbulkan kejadian tersebut.

Data dikumpulkan dengan cara wawancara dan menyebarkan kuesioner kepada responden. Populasi dalam penelitian ini adalah siswa kelas XI SMK Negeri 4 Balikpapan yang berjumlah 387 siswa kemudian 
diambil sampel menjadi 79 siswa. Sebelum peneliti menyebarkan kuesioner terlebih dahulu melakukan uji validitas dan reliabilitas. Dengan diperolehnya validitas butir setiap butir dapat diketahui dengan pasti butir manakah yang tidak memenuhi syarat, sehingga peneliti dapat mengganti ataupun merevisi butirbutir yang dimaksud.

\section{Reliabilitas menunjukkan}

kemampuan memberikan hasil pengukuran yang tetap (Purwanto, 2007:196). reliabilitas dengan uji

statistik cronbach alpha. Suatu konstruk atau variabel dikatakan reliable jika memberikan nilai a $>$ 0,60 dan tidak reliable jika nilai a $<$ 0,60 (Ghozali 2009:42). Setelah data yang terkait dengan masalah dikumpulkan, maka selanjutnya dilakukan penganalisisan. Dalam penelitian ini alat analisis data yang digunakan untuk menguji hipotesis dengan menggunakan regresi linier berganda melalui program computer SPSS 20. Analisis regresi ini digunakan untuk mengetahui arah dan besarnya pengaruh pendidikan kewirausahaan dan kepribadian terhadap minat berwirausaha siswa.

Selain melakukan uji $t$ dan uji f dalam penelitian ini, peneliti juga melakukan uji normalitas dan linieritas. Dan uji asumsi klasik yaitu, uji heterokedastisitas, uji multikolinieritas dan uji auto korelasi. Adapun tujuan dari hipotesis dalam penelitian ini yaitu untuk mengetahui pengaruh pendidikan kewirausahaan dan kepribadian terhadap minta berwirausaha.

\section{HASIL DAN PEMBAHAHSAN}

$\begin{array}{lcr}\text { Data } & \text { yang } & \begin{array}{r}\text { berhasil } \\ \text { dikumpulkan }\end{array} \\ \text { dari } & \text { kuesioner } \\ \text { menunjukkan } & \text { bahwa } & \text { pendidikan } \\ \text { kewirausahaan } & \text { tidak } & \text { berpengaruh }\end{array}$
secara parsial terhadap minat berwirausaha sedangkan kepribadian berpengaruh secara parsial terhadap minat berwirausaha. Sedangkan pendidikan kewirausahaan dan kepribadian berpengaruh secara simultan terhadap minat berwirausaha siswa kelas XI SMK Negeri 4 Balikpapan.

dibuktikan dengan uji $t$ dimana $_{h} \quad 0,634<1,991$. Dan taraf signifikan $\alpha=0,528>\alpha=0,05(5 \%)$ yaitu dalam taraf kepercayaan dalam pengujian sebesar 95\%. Berdasarkan hasil analisis data di atas dapat dilakukan pembuktian hipotesis sebagai berikut bahwa pendidikan kewirausahaan ( 1) tidak

berpengaruh terhadap minat berwirausaha $(\mathrm{Y})$.

dibuktikan dengan uji t
dimana ${ }_{h} 4,630>1,991$. Dan taraf
signifikan $\alpha=0,000>\alpha=0,05(5 \%)$
yaitu dalam taraf kepercayaan dalam
pengujian sebesar 95\%. Berdasarkan
hasil analisis data di atas dapat
dilakukan pembuktian hipotesis
sebagai berikut bahwa
kepribadian ( 2 ) berpengaruh terhadap
minat berwirausaha (Y). Dari
perhitungan uji F tersebut
menghasilkan $h$ = 16,229 . Dengan
demikian sesuai kriteria pengujian
signifikansi regresi, bahwa ${ }_{h}$ harus
lebih besar dari. diperoleh hasil
perhitungan


$16,229>3,12$ dan nilai signifikansi

$0,00<0,05$.

Secara parsial berdasarkan

hasil pengujian diperoleh nilai untuk variabel pendidikan kewirausahaan sebesar 0,634. Jika dibandingkan dengan nilai sebesar 1,991. y yang diperoleh lebih kecil dari pada nilai dan nilai signifikansinya adalah $0,528>$

0,05 . Maka hipotesis ditolak yang berarti tidak ada pengaruh antara Pendidikan Kewirausahaan terhadap Minat berwirausaha.

Kemudian secara parsial berdasarkan hasil pengujian diperoleh nilai $_{h} \quad$ variabel kepribadian sebesar 4,630. Jika dibandingkan

dengan nilai yang sebesar 1,991 . yang diperoleh lebih besar dari pada nilai dan nilai signifikansinya $0,000<$ 0,05 . Maka

hipotesis diterima yang berarti ada pengaruh antara kepribadian terhadap minat berwirausaha.

Adapun berdasarkan hasil pengujian secara simultan di dapat sebesar 16,229. pada tingkat signifikansi $5 \%$ dan dfl sebesar $\mathrm{k}=2$ dan df2 sebesar N-k-1 = 79-2-1 = 76 adalah sebesar 3,12 dengan nilai signifikansi $0,000<0,05$. Jika kedua nilai $\mathrm{F}$ dibandingkan, maka nilai ${ }_{h}$ jauh lebih besar dari nilai sehingga hipotesis diterima. Yang artinya pendidikan kewirausahaan dan kepribadian berpengaruh secara bersama-sama terhadap minat berwirausaha siswa XI SMK Negeri 4 Balikpapan.
Hasil tersebut sesuai dengan pengamatan dan analisis data yang dilakukan oleh peneliti di SMKN 4 Balikpapan. Berdasarkan teori dari Bygrave (Alma, 2013:11) terdapat tiga faktor yang berperan dalam meningkatkan minat berwirausaha yaitu hubungan personal (pribadi), hubungan dengan keluarga dan hubungan dengan lingkungan.

\section{KESIMPULAN}

Pendidikan kewirausahaan tidak memiliki pengaruh terhadap minat berwirausaha siswa kelas XI SMK Negeri 4 Balikpapan Tahun Ajaran 2017/2018, dengan nila 1,991. kepribadian memiliki pengaruh terhadap minat berwirausaha siswa kelas XI SMK Negeri 4 Balikpapan Tahun Ajaran 2017/2018, dengan nilai ${ }_{h} \quad 4,630$ $>1,991$. Yang artinya kepriabdian ( 2) memiliki pengaruh

$46,30 \%$ terhadap dan minat berwirausaha $(\mathrm{Y})$.

Pendidikan kewirausahaan ( 1 ) dan kepribadian ( 2) secara bersamasama berpengaruh terhadap Minat Berwirausaha (Y) siswa kelas XI SMK Negeri 4 Balikpapan Tahun Ajaran 2017/2018, dengan nilai $_{h} \quad 16,229>3,12$ 


\section{DAFTAR PUSTAKA}

Alma, Buchari (2007). Kewirausahaan. Bandung: Alfabeta

Arikunto, Suharsimi (2006) Uji Validitas dan Reliabilitas. Tersedia online di http://dataolah.blogspot.co.id/2012/03 /uji-validitas-dan-reliabilitas.html 2017

diaksespada tanggal 2 November

Arikunto, Suharsimi (2014). Prosedur Penelitian:Suatu

PendekatanPraktik. Jakarta: Rineka Cipta Budy, Doddy Astya (2017). Pengaruh Pendidikan Kewirausahaan dan Motivasi Kewirausahaan Terhadap Keterampilan Berwirausaha Mahasiswa Universitas 17 Agustus 1945 Jakarta. Jurnal Online dan Internasional. Vol.1 no 4 hal 7-22

Cahyono, Eko Budi \& Umam Muh. Khotibul(2017). Pengaruh Motivasi Berwirausaha dan Kemampuan Berpikir Kreatif Terhadap MInat Berwirausaha Siswa Teknik Pemesinan. Jurnal Pendidikan Vokasional Teknik Mesin Vol. 5 no 4 hal 277-284

Citradewi, Adelina dan Margunani (2016). Pengaruh Kepribadian, PendidikaN Kewirausahaan, Dan Lingkungan Keluarga Terhadap aktivitas Berwirausaha Mahasiswa Universitas Negeri Semarang. Jurnal Pendidikan Ekonomi. Vol. 5 no 2 hal 519-531

Daryanto, (2012). Pendidikan Kewirausahaan. Yogyakarta: Gava Media

Iswandari, Asti (2013). Pengaruh Motivasi Intrinsik, Pengetahuan Kewirausahaan, Dan Kepribadian Terhadap Minat Berwirausaha Pada Siswa SMKN 12 Surabaya. Jurusan Ekonomi Pendidikan Vol. 1 No. 2 hal 152-162

Lestari, Anis, Hasiolan Aleonardo B dan Minarsih Maria M (2016).
Pengaruh Sikap Mandiri,
Lingkungan Keluarga
Dan Motivasi Terhadap Minat
Berwirausaha Para Remaja.
Jurusan Manajemen Vol. 2 No. 2

Mahesa, Aditya Dion dan Rahardja Edy (2012). Analisis Faktor-Faktor Yang Mempengaruhi Minat Berwirausaha. Jurusan Manajemen Fakultas Ekonomika Vol. 1 no 1 hal 130-136

Munib dkk. (2004). Pengantar Ilmu Pendidikan. Semarang: UPT MK UNNES

Putri, Ni Luh Wahyuni Widya

(2014) Pengaruh Pendidikan

Kewirausahaan Terhadap Minat

Mahasiswa Untuk Berwirausaha

Pada Mahasiswa Pendidikan

Ekonomi Universitas Pendidikan

Ganesha. Jurusan Pendidikan

Ekonomi.

Rifai, Indra Abintya, dan D.W.P Sucihatiningsih. (2016) Pengaruh Pendidikan Kewirausahaan dan Pelaksanaan Kegiatan Business

Center Terhadap Minat Berwirausaha Siswa Kelas XI Jurusan Pemasaran SMK Neger 2 Semarang Tahun Ajaran 2015/2016. Journal of Economic Education Vol. 5 no 1 hal 39-51

Safitri, Anindawati Rini, dan Rustiana Ade. (2016). Pengaruh Pendidikan Kewirausahaan dan Kepribadian Terhadap Minat Berwirausaha Siswa Jurusan Pemasaran. Jurusan Pendidikan Ekonomi, UNS. Vol. 5 No. 3 hal 889-901

Sudarmanto R. Gunawan. (2013). Statistik Terapan Berbasis Komputer. Jakarta: Mitra Wacana Media

Sugiyono, (2010). Pengumpulan data dan instrumen penelitian. Tersedia online di https://afidburhanuddin.wordpress.co $\underline{\mathrm{m} / 2013 / 05 / 21 / \text { pengumpulan-data- }}$ dan-instrumen-penelitian/ diakses pada tanggal 2 November 2017 


\begin{tabular}{cccc}
$\begin{array}{l}\text { Sugiyono, (2012). } \\
\text { instrumen }\end{array}$ pengumpulan data dan & Sugiyono. & (2014). Metode \\
online & Tersedia & Penelitian Kuantitatif Kualitatif \\
https://afidburhanuddin.wordpress.co & di & dan R\&Dana, Yuyus, dan Bayu, Kartib (2010). \\
\hline $\mathrm{m} / 2013 / 05 / 21 /$ pengumpulan-data- & Kewirausahaan - Pendekatan \\
\hline dan-instrumen-penelitian/ diakses & Karakteristik Wirausahawan Sukses. \\
pada tanggal 2 November 2017 & Jakarta: Prenadamedia Group
\end{tabular}

